Volume 2, No. 1, 2022, 80-88

\title{
MANAJEMEN KOMPETENSI SOSIAL GURU DALAM MENINGKATKAN EFEKTIVITAS PEMBELAJARAN SISWA DI PAUD TK NEGERI PEMBINA LAMPUNG TENGAH
}

\author{
Novita Widiastuti ${ }^{1}$ M.Ihsan Dacholfany ${ }^{2 *}$ Sudirman Aminin $^{3}$ \\ ${ }^{1,2,3}$ Universitas Muhammadiyah Metro \\ E-mail: $\quad$ novitawidiastuti25@gmail.com ${ }^{1)}$ \\ muhammadihsandacholfany@gmail.com$*^{2)}$ \\ sudirman.am57@gmail.com3
}

\begin{abstract}
Abstrak
Manusia adalah makhluk sosial sehingga sebagian besar dari kehidupannya melibatkan interaksi dengan orang lain, dengan demikian seseorang akan selalu berinteraksi satu sama lain. Guru perlu memiliki kemampuan sosial dalam rangka pelaksanaan proses pembelajaran yang efektif Tujuan penelitian ini adalah untuk mendeskripsikan manajemen kompetensi sosial guru melalui fungsi manajemen seperti perencanaa, pengorganisasian, pelaksanaan dan pengawasan. Penelitian ini termasuk dalam penelitian kualitatif, dengan sumber data 10 informan. Tekhnik pengumpulan data dilakukan dengan fenomenologi dengan menggunakan observasi, wawancara dan dokumentasi. Hasil penelitian ini menunjukkan bahwa (1) perencanaan manajemen kompetensi sosial guru dalam meningkatkan efektivitas pembelajaran siswa adalah melalui rapat antara kepala sekolah, pendidik, tenaga kependidikan dan komite sekolah yang di lengkapi dengan kegiatan utama antar guru, siswa dan orang tua siswa.(2) pengorganisasian manajemen kompetensi sosial guru dalam meningkatkan efektivitas pembelajaran siswa berorientasi pada pembentukan tim guru sesuai dengan tugas pokok dan fungsinya, (3) pelaksanaan manajemen kompetensi sosial guru dalam meningkatkan efektivitas pembelajaran siswa berorientasi pada pemahaman sosialisasi kepada siswa, guru dan orang tua siswa.(4) pengawasan manajemen kompetensi sosial guru dalam meningkatkan efektifitas pembelajaran siswa dilakukan melalui pengamatan harian oleh warga sekolah, dan secara berkala melalui supervisi guru oleh kepala sekolah dalam peningkatan efektivitas pembelajaran siswa.
\end{abstract}

Kata kunci: Kata kunci 1; komptensi sosial guru 2; efektivitas pembelajaran siswa.

\begin{abstract}
Humans are social creatures so that most of their lives involve interaction with other people, thus someone will always interact with each other. Teachers need to have social skills in order to implement an effective learning process. The purpose of this study is to describe the management of teachers' social competence through management functions such as planning, organizing, implementing and supervising. This research is included in qualitative research, with data sources 10 informants. The technique of data collection is phenomenology using observation, interviews and documentation. The results of this study indicate that (1) the planning of teacher social competence management in increasing the effectiveness of student learning is through meetings between school principals, educators, education staff and school committees which are equipped with main activities between teachers, students and parents of students. (2) organizing the management of teacher social competence in increasing the effectiveness of student learning is oriented to the formation of a team of teachers in accordance with their main tasks and functions, (3) the implementation of teacher social competence management in improving the effectiveness of student learning is oriented towards understanding socialization to students, teachers and parents of students.(4) supervision of the management of teacher social competence in improving the effectiveness of student learning is carried out through daily observations by school residents, and periodically through teacher supervision by the principal in increasing the effectiveness of student learning.
\end{abstract}

Keywords: teacher social competence; student learning effectiveness 


\section{PENDAHULUAN}

Manusia adalah makhluk sosial sehingga sebagian besar dari kehidupannya melibatkan interaksi dengan orang lain, dengan demikian seseorang akan selalu berinteraksi satu sama lain, dengan berbagai macam individu tentunya dengan pola kepribadian, keunikan dan kekhasan masing-masing. Guru perlu memiliki kemampuan sosial dalam rangka pelaksanaan proses pembelajaran yang efektif, dimana kriteria kompetensi sosial meliputi: bersikap inklusif, bertindak objektif serta tidak diskriminatif karena pertimbangan jenis kelamin, agama, ras, kondisi fisik, latar belakang keluarga, dan status sosial ekonomi, berkomunikasi secara efektif, simpatik dan santun dengan sesama pendidik, tenaga kependidikan, orang tua dan masyarakat, beradaptasi di tempat bertugas diseluruh wilayah Republik Indonesia yang memiliki keragaman sosial budaya, berkomunikasi dengan komunitas profesi sendiri dan profesi lain secara lisan dan tulisan atau bentuk lain. Keberhasilan proses belajar siswa salah satunya ditentukan oleh kompetensi sosial guru. Kompetensi sosial guru dapat diartikan sebagai kemampuan seorang guru dalam berkomunikasi atau berhubungan secara efektif dengan peserta didik, sesama pendidik, tenaga kependidikan, orang tua/wali, dan masyarakat sekitar. Seorang guru harus mempunyai semua aspek kompetensi sosial sehingga proses belajar mengajar dapat terlaksana dengan baik.

Berdasarkan Undang-Undang Nomor 14 Tahun 2005 tentang Guru dan Dosen pada Bab IV Pasal 10 menyebutkan, ada empat kompetensi kepribadian guru, yakni Kompetensi Pedagogik, Kompetensi Kepribadian, Kompetensi Profesional, dan Kompetensi Sosial. Keempat kompetensi tersebut harus dimiliki guru, diminta ataupun tidak, mereka harus melakukannya secara tulus. Kompetensi pedagogik meliputi pemahaman guru terhadap peserta didik, perancangan dan pelaksanaan pembelajaran, evaluasi hasil belajar, dan pengembangan peserta didik. Kompetensi kepribadian merupakan kemampuan personal yang mencerminkan kepribadian yang mantab, stabil, dewasa, arif, berwibawa dan berahlak mulia. Kompetensi sosial merupakan kemampuan guru untuk berkomunikasi dan bergaul secara efektif dengan peserta didik, sesama pendidik, tenaga kependidikan, orang tua/wali peserta didik, dan masyarakat sekitar. Sebab tanpa komunikasi, interaksi antar manusia, baik secara perorangan, kelompok, ataupun organisasi tidak mungkin dapat terjadi. Hal ini dapat berdampak negativ bagi semua pihak. Kompetensi professional merupakan penguasaan materi pembelajaran secara luas dan mendalam, yang mencakup penguasaan materi kurikulum mata pelajaran di sekolah dan substansi keilmuan yang menaungi materinya, serta penguasaan terhadap stuktur dan metodologi keilmuannya.

Secara teoritis, keempat kompetensi ini dapat dipisah-pisahkan satu sama lain, tetapi secara praktis sesungguhnya keempat jenis kompetensi tersebut tidak mungkin dipisah-pisahkan. Empat kompetensi tersebut saling berhubungan secara padu dalam identitas guru. Guru yang terampil mengajar, tentu memiliki kemampuan pedagogik, tetapi harus juga memiliki kepribadian yang baik dan mampu melakukan social adjustment ( penyesuaian sosial) dalam masyarakat, karena guru selalu dijadikan panutan oleh siswa dan masyarakat tempat sekitarnya

Manajemen adalah suatu proses dimana seseorang dapat mengatur segala sesuatu yang dikerjakan oleh individu atau kelompok. Manajemen perlu dilakukan guna mencapai tujuan atau target dari individu atau kelompok tersebut secara kooperatif menggunakan sumber daya yang tersedia(Wijayanto \& SPi, 2013). 
Setiap ahli memberikan pandangan yang berbeda tentang batasan manajemen, karena memberi arti universal yang dapat diterima semua orang, namun demikian dari pikiran-pikiran ahli tentang manajemen kebanyakan menyatakan bahwa manajemen merupakan suatu proses tertentu yang menggunakan kemampuan atau keahlian untuk mencapai suatu tujuan yang didalam pelaksanaannya dapat mengikuti alur keilmuwan secara ilmiah dan dapat menonjolkan kekhasan atau gaya manajer dalam mendayagunakan kemampuan orang lain (Tim Dosen Administrasi Pendidikan Universitas Indonesia, 2017). Manajemen adalah cara pencapaian tujuan yang telah ditentukan terlebih dahulu dengan melalui kegiatan orang lain (Defi, 2020). Manajemen adalah suatu proses saat suatu kelompok orang bekerja sama mengarahkan orang lainnya untuk bekerja mencapai tujuan yang sama (Massie dan Douglas) (Hanafi, 2008). Manajemen adalah menciptakan lingkungan yang efektif agar orang bisa bekerja di organisasi formal (Bukar, 2021)

Manajemen adalah perencanaan, pengorganisasian, pengarahan, pengendalian, aktivitas anggota organisasi, dan kegiatan yang menggunakan semua sumber daya organisasi untuk mencapai tujuan organisasi yang telah ditentukan (Gilbert, Stoner, \& Freeman, 2009).

Pengertian manajemen di atas mencakup beberapa kata kunci: 1. proses yang merupakan kegiatan yang direncanakan, 2. kegiatan merencanakan, mengorganisasi, mengarahkan, dan mengendalikan yang sering disebut sebagai fungsi manajemen, 3. koordinasi kegiatan, 4. tujuan organisasi yang ingin dicapai melalui aktivitas tersebut, 5. sumber daya organisasi yang digunakan untuk mencapai tujuan tersebut, 6. pencapaian tujuan dengan efektif dan efisien.

Berdasarkan pendapat para ahli di atas maka disimpulkan bahwa yang dimaksud dengan manajemen adalah ilmu mengatur proses untuk mencapai tujuan yang telah ditetapkan sebelumnya guna mencaai hasil yang sesuai

Peningkatan merupakan kegiatan untuk memajukan sesuatu ke suatu arah yang lebih bail lagi daripada sebelumnya. Pengertian efektivitas secara umum menunjukkan sampai seberapa jauh tercapainya suatu tujuan yang terlebih dahulu ditentukan. Kata efektivitas lebih mengacu pada out put yang telah ditargetkan. Efektivitas merupakan faktor yang sangat penting dalam pelajaran karena menentukan tingkat keberhasilan suatu model pembelajaran yang digunakan(Shofa, 2020).

Guru pendidikan anak usia dini di mata masyarakat pada umumnya dan di mata para orang tua siswa pada khususnya merupakan panutan yang perlu dicontoh sebagai suri tauladan dalam kehidupan sehari-hari. Guru merupakan tipe dan makhluk yang diberi tugas membina dan membimbing masyarakat kearah norma yang berlaku, untuk itu guru pendidikan anak usia dini perlu memiliki kemampuan sosial dan mampu beradaptasi dengan masyarakat, agar proses belajar-mengajar yang diselenggarakan di sekolah tersebut berjalan lancar dan hubungan sekolah dengan masyarakat berjalan dengan baik. Bila kemampuan sosial guru dan beradaptasinya dengan masyarakat berjalan dengan lancar, maka kegiatan sekolah yang berkaitan dengan kemasyarakatan dapat berjalan dengan lancar.

\section{METODE PENELITIAN}

Penilitian ini merupakan penelitian dengan pendekatan kualitatif. Menurut Moleong (2017: 6) "Penelitian kualitatif adalah penelitian yang bermaksud untuk memahami tentang apa yang dialami oleh subyek penelitian misalnya perilaku, persepsi, 
motivasi, tindakan dan lain-lain, secara holistik dan dengan cara deskripsi dalam bentuk kata-kata dan bahasa pada suatu konteks khusus yang alamiah dan dengan memanfaatkan berbagai metode alamiah".

Jenis penelitian yang digunakan penulis dalam penelitian ini adalah penelitian lapangan (field research), oleh karena itu obyek penelitiannya adalah berupa obyek di lapangan yang sekiranya mampu memberikan informasi tentang kajian penelitian. Proses pembelajaran akan berlangsung dalam setting alami (natural setting) penelitian diarahkan ada kondisi aslinya dimana subjek penelitian berada. Kondisi subjek tidak disentuh oleh perlakuan khusus yang dikendalikan peneliti. Pada saat pengumpulan data, peneliti melakukan kontak langsung dengan subjek penelitian agar dapat mengamati sikap, perilaku dan pendapat subyek secara langsung. Dalam penelitian ini peneliti bertindak sebagai pengamat, mempelajari suatu proses atau penemuan secara alami, mencatat menganalisis, menafsirkan dan melaporkan serta menarik kesimpulan dari proses tersebut. Penelitian ini diharapkan dapat menemukan sekaligus mendeskripsikan data secara menyeluruh mengenai manajemen kompetensi sosial guru dalam meningkatkan efektivitas pembelajaran siswa PAUD TK Negeri Pembina Lampung Tengah

\section{HASIL DAN PEMBAHASAN}

Bab ini membahas tentang yang terkait dengan apa yang telah di lakukan dan apa yang di amati, berdasarkan hasil dari paparan data dan temuan hasil penelitian. Hal ini disesuaikan dengan fokus penelitian, yaitu ; (1) Perencanaan kompetensi sosial guru dalam meningkatkan efektivitas pembelajaran di PAUD TK Negeri Pembina Lampung Tengah, (2) Pengorganisasian kompetensi sosial guru dalam meningkatkan efektivitas pembelajaran di PAUD TK Negeri Pembina Lampung Tengah, (3) Pelaksanaan kompetensi sosial guru dalam meningkatkan efektivitas pembelajaran di PAUD TK Negeri Pembina Lampung Tengah,(4) Pengawasan kompetensi sosial guru dalam meningkatkan efektivitas pembelajaran di PAUD TK Negeri Pembina Lampung Tengah.

Memahami istilah manajemen, pendekatan yang di aplikasikan adalah berdasarkan pengalaman seseorang pimpinan. Manajemen sebagai suatu sistem merupakan suatu proses untuk mencapai target organisasi secara maksimal dan komprehensif. Untuk meraih target organisasi dilaksanakan dengan pengelolaan fungsi - fungsi perencanaan (Planning), pengorganisasian (organizing), penyusunan personalia atau kepegawaian (Staffing), pengarahan dan kepemimpinan (learding), dan pengawasan (controlling) (Yusuf, 2020).

\section{Data Perencanaan Kompetensi Sosial Guru Dalam Meningkatkan Efektivitas Pembelajaran Siswa}

Sesuai dengan visi, misi dan tujuan sekolah maka perencanaan merupakan sebuah langkah awal yang harus di tempuh dalam menyusun sebuah program. Perencanaan kompetensi sosial guru dalam meningkatkan efektivitas pembelajaran di TK Negeri Pembina Lampung Tengah, dinilai sangat penting berdasarkan pertimbangan perlunya memberikan motivasi kepada guru, dalam peningkatan kompetensi sosialnya sesuai butir indikator kompetensi sosial guru serta memberikan pembekalan untuk mewujudkan pembelajaran yang baik. Demikian halnya dengan program peningkatan efektivitas belajar siswa, perencanaan program ini di lakukan di sekolah dengan sasaran pada tiga hal yakni kegiatan intrakurikuler, ko- kurikuler, dan 
ekstrakurikuler. Melalui bertukar pengalaman dalam pembelajaran dengan teman sejawat, guru akan meningkatkan pengetahuan dan keterampilan, hal ini tentu akan berkaitan dengan kompetensi sosial guru dalam bersosialisasi dan peningkatan kualitas guru. Guru akan terlatih dalam berkomunikasi, bergaul, bekerjasama, dan memberi kepada orang lain.

Perencanaan berbagai program kegiatan sekolah dan program pembelajaran, yaitu:

1. Program Tahunan

Program tahunan merupakan rencana kegiatan dan pembelajaran untuk satu tahun ajaran, yaitu terdiri dari program semester satu dan semester dua. Dalam perencanaan tahunan terdiri dari kegiatan sekolah seperti: penerimaan murid baru, pengenalan visi misi sekolah, pemberian vitamin, pelaksanaan kegiatan pembelajaran selama satu tahun, kunjungan rumah, kegiatan puncak tema/market day/kebun kelas, menyapa anak melalui video conference, kegiatan parenting.

2. Program semester

Program semester yaitu perencanaan pembelajaran untuk satu semester yang terdiri dari tema, sub tema, kompetensi dasar, waktu.. Program semester terjabarkan kedalam Rencana Pelaksanaan Pembelajaran Mingguan dan Rencana Pelaksanaan Pembelajaran harian yang penerapan kepada siswa dengan mengintegrasikan nilainilai kultural, sosial, self - Regulation, kemampuan untuk memahami orang lain dan identitas diri yang positif.

Perencanaan kompetensi sosial guru di awali adanya rapat antara kepala sekolah, pendidik dan tenaga kependidikan, komite serta staff dan juga siswa yang terkait dalam pembelajaran di sekolah tersebut, rapat tersebut membahas perencanaan, pengorganisasian, pelaksanaan dan pengawasan.

\section{Data Pengorganisasian Kompetensi Sosial Guru Dalam Meningkatkan Efektivitas Pembelajaran Siswa}

Dari hasil observasi, dokumentasi dan wawancara pengorganisasian manajemen komptensi sosial guru dalam meningkatkan efektivitas pembelajaran siswa di TK Negeri Pembina Lampung Tengah berkaitan dengan fungsi - fungsi struktur organisasi di sekolah. Kompetensi sosial di butuhkan bagi seorang guru agar mampu berinteraksi dan berkomunikasi di lingkungan sekolah. Salah satu yang dapat dilakukan adalah dengan melalui pembinaan dari kepala sekolah dan pengembangan keprofesian guru berkaitan dengan kompetensi sosial dan efektivitas pembelajaran.

Pembinaan yang dilakukan kepala sekolah kepada guru-guru sesuai dengan tugasnya dan berkaitan dengan kompetensi sosial yaitu:

1. Kompetensi sosial guru terhadap siswa

Bagaimana guru di TK Negeri Pembina Lampung Tengah untuk bersikap terbuka terhadap siswa, mengembangkan sikap komunikasi yang baik, menunjukkan sikap objektif terhadap seluruh siswa, menunjukkan sikap mengasihi terhadap siswa, sikap adil terhadap semua siswa agar efektivitas pembelajaran dapat tercapai.

2. Kompetensi sosial guru dengan teman sejawat

Guru harus mempunyai sikap terbuka kepada teman sejawat, berbagi pengalaman, mau menerima kritik dan saran konstruktif dari teman, berkomunikasi dialogis, peduli terhadap lingkungan sekitar dan memanfaatkan lingkungan untuk sumber belajar, mengasihi kepada setiap teman, dan bersikap adil terhadap semua teman 
sejawat agar tercipta suasana yang nyaman dalam bekerja untuk kemajuan sekolah dan tercapainya tujuan pembelajaran.

3. Kompetensi sosial guru dengan orang tua peserta didik

Guru harus menjalin komunikasi dialogis dengan orang tua/wali siswa, mengkomunikasikan secara obyektif berdasarkan data dan fakta tentang program pembelajaran dan kemajuan siswa yang bersangkutan, membina hubungan baik, supel dan simpatik dengan orangtua/wali siswa, memiliki kepekaan intrapersonal terhadap orang tua siswa, mau menerima kritik dan saran dari orang tua siswa agar program manajemen kompetensi sosial guru untuk meningkatkan efektifitas pembelajaran siswa dapat berjalan dengan baik.

Guru sebagai pendidik dapat melaksanakan perannya jika guru tersebut memenuhi kriteria yang ada pada standar kompetensi seorang pendidik, salah satunya adalah kompetensi sosial. Pendapat di perkuat oleh Malik (2003:42-43) yang mengatakan bahwa guru akan mampu menciptakan pembelajaran yang efektif misalnya guru mempunyai ketrampilan dalam membina hubungan antara guru dengan murid, guru dengan sesama guru, guru dengan kepala sekolah, guru dengan komite sekolah serta hubungan antara guru dengan masyarakat dan lingkungan sekitar.

TK Negeri Pembina Lampung Tengah dalam memudahkan pembelajaran yang terintegrasi dalam kegiatan membentuk sebuah tim kerja yang bertujuan untuk memudahkan dalam melaksanakan kegiatan belajar mengajar, pembagian kelompok tugas kerja sesuai dengan kemampuan dan kriteria guru. Kepala sekolah membuat pembagian tugas dan tanggung jawab yang jelas untuk pelaksanaan kegiatan dan pembelajaran.

\section{Data Pelaksanaan Kompetensi Sosial Guru Dalam Meningkatkan Efektivitas Pembelajaran Siswa}

Hasil dari penelitian pelaksanaan kompetensi sosial guru dalam meningkatkan efektivitas pembelajaran siswa di TK Negeri Pembina Lampung Tengah yaitu pembuatan perangkat pembelajaran, yaitu di awali program semester (PROSEM), rencana pelaksanaan pembelajaran mingguan (RPPM), rencana pelaksaan pembelajaran harian (RPPH), format penilaian dan dokumentasi yang terintegrasi dengan kompetensi sosial guru.

Pelaksanaan kompetensi sosial guru dalam meningkatkan efektivitas pembelajaran siswa dilakukan oleh guru dengan memaksimalkan kompetensi sosial guru terhadap siswa agar masa emas anak (golden age) dapat berkembang dengan maksimal, dimana pembelajaran dilaksanakan dengan memperhatikan:

a. Karakteristik tujuan pembelajaran, yaitu mengembangkan domain nilai agama dan moral, sosial emosional, fisik motorik, kognitif, bahasa, dan seni. Selain dari aspek domain tersebut, dapat juga untuk mengembangkan pemahaman anak mengenai nilai-nilai etika, sopan santun dan sebagainya

b. Karakteristik anak sebagai peserta didik baik usianya maupun kemampuannya. Setiap anak memiliki karakteristik dan kemampuan yang berbeda-beda. Guru harus peka dalam membaca dua hal tersebut, sehingga dapat membuat strategi yang sesuai dengan usia dan kemampuan anak didiknya agar tidak terjadi suatu pemaksaan terhadap kemampuan anak, dan berlangsung dalam suasana penuh kasih sayang. 
c. Karakteristik tempat yang akan digunakan untuk kegiatan pembelajaran apakah di luar atau di dalam ruangan, dengan memanfaatkan lingkungan sebagai sumber belajar, dimana lingkungan juga akan mempengaruhi perilaku anak.

d. Karakteristik tema atau bahan ajar yang akan disajikan kepada anak. Guru dapat melibatkan orang tua dan lingkungan sekitar sekolah dalam menerapkan tema dan menetapkan bahan ajar untuk anak, dengan berkomunikasi dan berinteraksi secara efektif dan efisien kepada orangtua siswa. Guru dapat melibatkan orang tua dan lingkungan sekitar sekolah dalam menerapkan tema dan menetapkan bahan ajar untuk anak. Misalnya, guru dapat memaksimalkan kekayaan alam yang ada di sekitar lingkungan sekolah untuk dijadikan bahan ajar. Dengan memaksimalkan potensi alam di sekitar lingkungan anak, maka anak akan menjadi lebih peka terhadap lingkungannya. Selain memaksimalkan potensi alam, dapat juga memaksimalkan potensi dari para orangtua murid. Misalnya, dengan mengundang orang tua murid dengan profesi tertentu sebagai guru tamu pada saat membahas tema yang sesuai (kelas inspirasi). Dengan begitu anak didik akan merasa bangga dengan orangtua mereka, dan bersemangat dalam kegiatan tersebut. Banyak hal yang dapat dilakukan untuk memotivasi anak agar menaruh minat yang besar pada setiap kegiatan yang akan disajikan. Dan hal yang menjadi pokok adalah menetapkan tema dan bahan ajar yang berguna, baik dan sesuai untuk anak serta dikemas secara menarik.

e. Karakteristik pola kegiatan yang akan digunakan apakah klasikal, kelompok atau individual dalam pendekatannya untuk memaksimalkan kreatifitas anak.

Guru memberikan pengarahan kepada anak dengan komuikasi dialogis, agar anak dalam melakukan kegiatan bisa memahami instruksi yang di berikan oleh guru. Anak akan bekerja sesuai dengan arahan yang diberikan oleh guru sebelumnya, sedangkan apabila arahan tidak diberikan dengan baik, maka anak akan diam saja atau terlihat bingung untuk memulai kegiatan. Namun tentu saja, daya tangkap setiap anak berbeda, oleh karena itu dibutuhkan kepekaan guru dalam membaca anak dan cara berkomunikasi yang sesuai dengan usia anak.

\section{Data Pengawasan Kompetensi Sosial Guru Dalam Meningkatkan Efektivitas Pembelajaran Siswa}

Hasil penelitian dan pembahasan pengawasan kompetensi sosial guru dalam meningkatkan efektivitas pembelajaran siswa dalam kelas sebenarnya. Manajemen kelas menggambarkan ketrampilan guru dalam merancang, menata dan menerapkan kurikulum, kemudian menjabarkan kedalam prosedur belajar mengajar dan sumber sumber belajar, serta merangsang untuk tercapainya suasana proses belajar yang efektif dan efisien. Hal ini di lakukan oleh peneliti seperti melaksanakanakan ketatausahaan kelas, pengelolaan indikator kompetensi sosial untuk kemajuan perkembangan anak di dalam kelas dengan bimbingan dan pemberian kasih sayang, pendekatan guru kepada murid secara individu.

Guru merupakan ujung tombak pencapaian tujuan pendidikan, dan guru juga harus mempunyai dedikasi yang tinggi, pengetahuan yang dalam tentang ilmu kependidikan, serta cerdas dalam menentukan tindakan yang tepat terhadap setiap permasalahan pendidikan yang dihadapi. 
Guru perlu memiliki kemampuan sosial dengan masyakat, dalam rangka pelaksanaan proses pembelajaran yang efektif. Dengan dimilikinya kemampuan tersebut, otomatis hubungan sekolah dengan masyarakat akan berjalan dengan lancar, sehingga jika ada keperluan dengan orang tua siswa, para guru tidak akan mendapat kesulitan.

Upaya kepala sekolah dalam peningkatan kompetensi sosial guru di TK Negeri Pembina Lampung Tengah Lampung dengan cara mensupervisi secara berkala. Hasil pengawasan dan evaluasi menjadi bahan acuan pengelolaan dalam program peningkatan pembelajaran di sekolah, sehingga sekolah ini secara berkesinambungan mengembangkan program pengembangan keprofesian guru berkelanjutan dalam berbagai lini kehidupan sosial di sekolah, kerjasama dengan orang tua siswa. Untuk dapat mendapatkan hasil yang baik maka kerjasama dilakukan bersama dengan orang tua siwa, kerjasama yang erat dan harmonis antara sekolah dengan orang tua wali. Informasi -informasi dari orang tua wali akan membantu guru untuk mengatasi kesulitan pembelajaran .

Dari hasil wawancara terkait dengan pengawasan(controlling) terhadap program - program yang sudah berjalan di sekolah agar dapat menjadi masukan untuk perbaikan sekolah di TK Negeri Pembina Lampung Tengah.

\section{KESIMPULAN}

Berdasarkan tujuan penelitian dapat disimpulkan bahwa manajemen kompetensi sosial guru dapat meningkatkan efektivitas pembelajaran siswa di Paud Tk Negeri Pembina Lampung Tengah.

\section{DAFTAR PUSTAKA}

Bukar, M. A. (2021). Comparative Study of Media Management in Nigeria: A Study of nta Zonal Centre Maiduguri and (FRCN) Peace fm Maiduguri. Journal of Media \& Management. SRC/JMM-132, 3.

Defi, W. F. (2020). Manajemen Karakter Peserta Didik Pesantren di Era Pandemi (Studi Kasus Smp Pesantren Modern Terpadu Prof. Dr. Hamka II Padang). Southeast Asian Journal of Islamic Education Management, 1(2), 146-151.

Gilbert, D. R., Stoner, J., \& Freeman, E. (2009). Management: Pearson Publication.

Hanafi, M. (2008). Konsep Dasar dan Perkembangan Teori Manajemen: Managemen.

Meleong, L. J. (2007). Metode Penelitian Kualitatif, penerbit PT Remaja Rosdakarya Offset: Bandung.

Moelong, L. J. 2017. Metode Penelitian Kualitatif. Remaja Rosdakarya Bandung.

Shofa, M. F. (2020). Inovasi Pembelajaran pada Pendidikan Anak Usia Dini dI Masa Pandemi Covid 19. BUANA GENDER: Jurnal Studi Gender dan Anak, 5(2), 86-96.

Tim Dosen Administrasi Pendidikan Universitas Indonesia. (2017). Manajemen Pendidikan: Alfabeta Bandung. 
Wijayanto, D., \& SPi, M. (2013). Pengantar manajemen: Gramedia Pustaka Utama.

Yuliani, T., \& Kristiawan, M. (2017). Peran Kepemimpinan Kepala Sekolah dalam Membina Kompetensi Sosial (Pelayanan Prima) Tenaga Administrasi

Sumadji, (2013). Revitalisasi Kelompok Kerja Guru (KKG) Upaya Meningkatkan Mutu Pendidikan. http://pendidikan.probolinggokab. Go.id. .

Trimo, (2007). Studi Kasus Pelaksanaan Kelompok Kerja Guru (KKG) di Gugus Inti 1 Kecamatan Kaliwungu Kabupaten Kendal tahun 2006/2007. http: // pasca.uns.ac.id/?p=684.

Zahroh, Aminatul, (2017). Kualitas pembelajaran melalui Dimensi Profesionalisme Guru. Bandung: Yrama Media. 